\title{
INFLUENCE OF REPETITIVE WORK ON WORK PRODUCTIVITY ON DEPARTMENT OF PACKAGING
}

\author{
DjokoAdiWalujo*) \\ ${ }^{*}$ Industrial Engineering Department, Faculty of Industrial Technology \\ University of PGRI Adi Buana Surabaya \\ email :djokoadiwalujo@unipasby.ac.id
}

\begin{abstract}
Sealing process requires an ergonomic attitude in work. If work posture is not ergonomic it can cause musculoskeletal system disorders. The purpose of this research to know the effect of repetitive work on work productivity on sealing activities in the packaging department based on RULA method. Data collection is done by direct observation and interview. Data obtained are analyzed, then the acquisition of grand scores is categorized based on the action level of the RULA. The posture of sealing process in the packaging department is in the fourth level action category which means that there is need for investigation and possible repairs.
\end{abstract}

\section{INTRODUCTION}

Some of the activities experienced by the workers in increasing the use of mechanization, automation at the speed of work, and the optimization of production capacity give some impact on the worker's body on the physical and psychic. Measurement methods used in improving the work system of workers in the packaging department is with nordic body map questionnaire, rapid upper limb assessment.

The nordic body map questionnaire is a questionnaire used to find out the inconvenience of the workers at work and the nordic body map questionnaire has been widely used by ergonomics experts to assess the severity of disorders of the skeletal and muscle systems and have considerable validity and reliability (Tarwaka, 2010). While the rapid upper limb assessment is a method developed in the field of ergonomics and can be used quickly to assess the working position or posture of the neck, back, arms of an operator's wrist and leg. In addition, this method is also influenced by coupling factors, external burden is supported by the body and worker activity. The assessment using the rapid upper limb assessment did not take long to complete and scoring general on the list of activities indicating the need for risk reduction caused by the operator's work posture (McAtamney, 2000).

Research on the effect of repetitive work in increasing the use of mechanization, automation at the speed of work, and the optimization of production capacity, is done to twelve workers in the packaging department with the following working methods, packaging process, sealing (cover packaging); checking sealing results (ensuring packaging in airtight conditions); and sew the packaging to look neat. Based on the above problems, this study aims to find out repetitive work can reduce the productivity of work in the packaging department.

Based on the above problems, this study aims to find out repetitive work can reduce the productivity of work in the packaging department. Some literature reviews include repetitive work, repetitive movements, theories about nordic body maps, Rapid Upper Limb Assessment (RULA), and previous researchers.

\section{LITERATURE REVIEW}

Rapid Upper Limb Assessment (RULA) was designed by Lynn McAtamney and Nigel Corlett (1993) which provides a calculation of 
the musculoskeletal load level in a job that poses a risk to the part of the body from the abdomen to the neck or upper limbs.

This method does not require special equipment in the assessment of posture of the neck, back and upper arms. Each movement is given a predefined score to facilitate the assessment of body posture, the body is divided into 2 group segments that are group $\mathrm{A}$ and group $\mathrm{B}$.

Rating Group Posture Body A consists of four parts that is:

- Upper Arm

Assessment is made on the angle formed by the upper arm according to the position of the torso during the work activity.

- Forearm

Assessment is performed on the angle formed by the forearm according to the position of the torso during the work activity.

- Wrist

Assessment is made on the angle formed by the wrist according to the position of the forearm while performing work activities.

- Wrist Round

For a round of wrists neutral posture is given a score:

$1=$ The middle position of the round

$2=$ On or near from round

The values of the upper arm posture, forearm, wrist and wrist round are inserted into Group A's posture chart to obtain a score.

- Added Activity Score

After the results obtained score for group A posture, then the score is added to the score of activity.
- Addition of load scores

Scores of additions with activity scores are added with the load score.Rating Group Posture Body B consists of five parts that is:

- Neck

Assessment is done to the position of the neck during the work activities whether the operator must perform extension or flexibility with a certain angle.

- Trunk

Assessment of the angle that the spine is formed in the body while performing work activities with a slope that has been classified.

- Legs

Assessment is done to the position of the foot during work activities whether the operator works with a normal position / balanced or resting on one leg straight.

The scores of posture neck, torso and foot posture scores are inserted into group B posture charts for a score.

- Addition of activity score

After the results obtained score for group $\mathrm{B}$ posture, then the score results are added with the score of activity.

- Addition of load scores

Scores of additions with activity scores are added with the load score.

To obtain a final score, the scores obtained for Group A and Group B postures are combined into tables. The final score is classified into several risk level categories. 
TiBuana

Journal of applied Industrial Engineering-University of PGRI Adi Buana

p-ISSN 2622-2027

$e$-ISSN 2622-2035

\section{RESEARCHMETHODOLOGY}

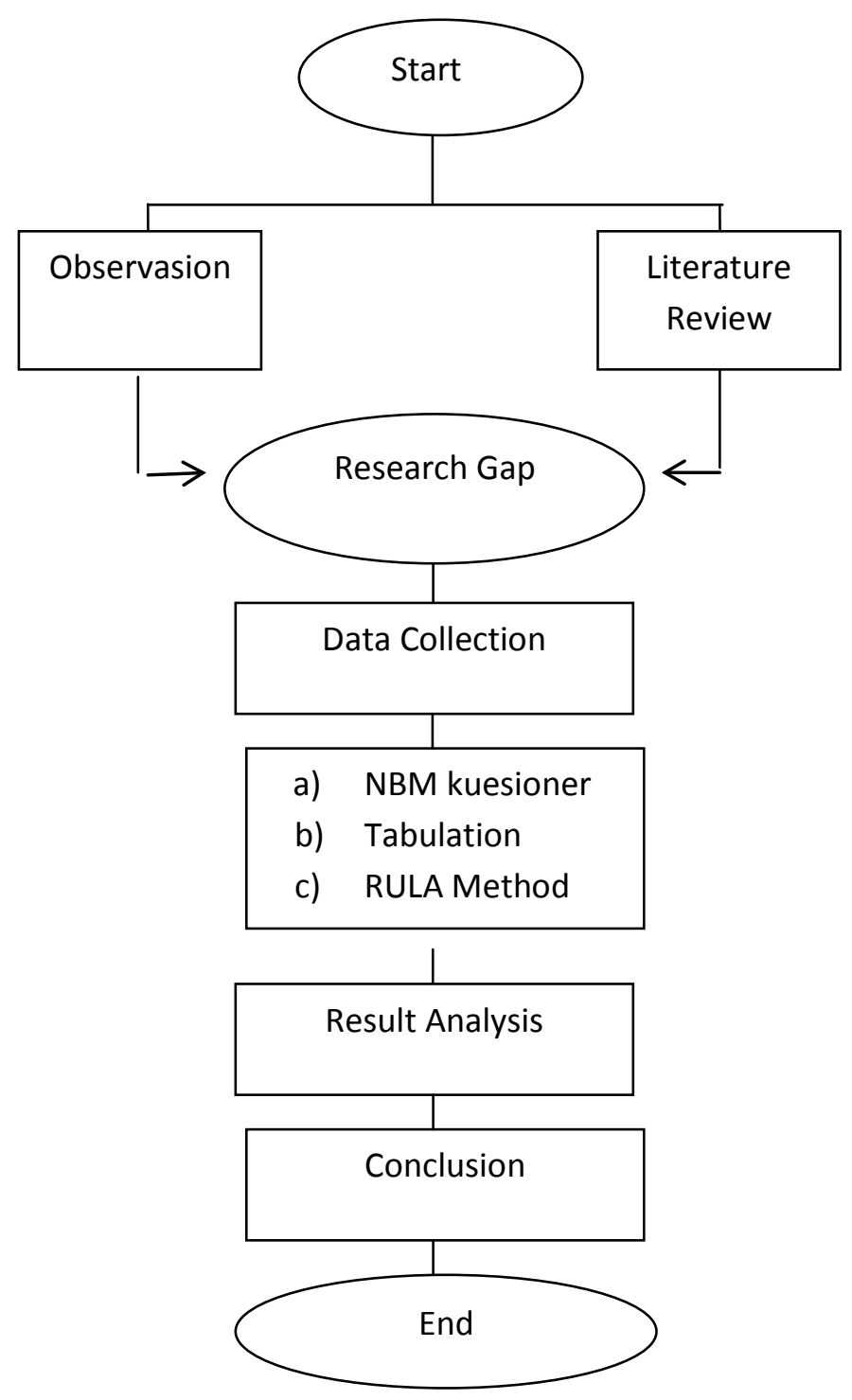

Figure 1.Flowchart Troubleshooting 
TiBuana

Journal of applied Industrial Engineering-University of PGRI AdiBuana

\section{DATA COLLECTION}

Table 1. Data on The Number Workers

\begin{tabular}{|c|c|c|c|c|c|}
\hline No & Name & Group & Age & Height & $\begin{array}{c}\text { Years } \\
\text { of } \\
\text { Service }\end{array}$ \\
\hline 1. & CaturAgil & A1 & 26 & $\begin{array}{c}160- \\
170\end{array}$ & $\begin{array}{l}5 \text { thsd } \\
10 \text { th }\end{array}$ \\
\hline 2. & HeriCahyono & A2 & 28 & $\begin{array}{c}\mathrm{cm} \\
160- \\
170\end{array}$ & $\begin{array}{l}5 \text { thsd } \\
10 \text { th }\end{array}$ \\
\hline 3. & Rudi Okda & A3 & 30 & $\begin{array}{l}160- \\
170 \\
\mathrm{~cm}\end{array}$ & $\begin{array}{l}5 \text { thsd } \\
10 \text { th }\end{array}$ \\
\hline 4. & Rozaq & A4 & 27 & $\begin{array}{l}171- \\
180 \\
\mathrm{~cm}\end{array}$ & $\begin{array}{l}5 \text { thsd } \\
10 \text { th }\end{array}$ \\
\hline 5. & Marzuki & B1 & 28 & $\begin{array}{c}160- \\
170\end{array}$ & $\begin{array}{l}5 \text { thsd } \\
10 \text { th }\end{array}$ \\
\hline 6. & Moch. Andrik & B2 & 27 & $\begin{array}{c}\mathrm{cm} \\
160- \\
170 \\
\mathrm{~cm}\end{array}$ & $\begin{array}{l}5 \text { thsd } \\
10 \text { th }\end{array}$ \\
\hline 7. & Hussein & B3 & 31 & $\begin{array}{l}171- \\
180 \\
\mathrm{~cm}\end{array}$ & $\begin{array}{l}5 \text { thsd } \\
10 \text { th }\end{array}$ \\
\hline 8. & DhonnySeptian & B4 & 29 & $\begin{array}{l}160- \\
170 \\
\mathrm{~cm}\end{array}$ & $\begin{array}{l}5 \text { thsd } \\
10 \text { th }\end{array}$ \\
\hline 9. & BeniLukito & C1 & 26 & $\begin{array}{c}160- \\
170\end{array}$ & $\begin{array}{l}5 \text { thsd } \\
10 \text { th }\end{array}$ \\
\hline 10. & Puspitono & $\mathrm{C} 2$ & 28 & $\begin{array}{l}171- \\
180 \\
\mathrm{~cm}\end{array}$ & $\begin{array}{l}5 \text { thsd } \\
10 \text { th }\end{array}$ \\
\hline 11. & AlfanSyaifudin & C3 & 25 & $\begin{array}{c}160- \\
170 \\
\mathrm{~cm}\end{array}$ & $\begin{array}{l}5 \text { thsd } \\
10 \text { th }\end{array}$ \\
\hline 12. & Yanuar & C4 & 26 & $\begin{array}{c}160- \\
170 \\
\mathrm{~cm}\end{array}$ & $\begin{array}{l}5 \text { thsd } \\
10 \text { th }\end{array}$ \\
\hline
\end{tabular}

Table 2. Characteristics of Respondents By

$$
\text { Sex }
$$

\begin{tabular}{ccc}
\hline Gender & Frequency & $\%$ \\
\hline
\end{tabular}

\begin{tabular}{ccc}
\hline Male & 12 & 100 \\
Female & 0 & 0 \\
Total & 12 & 100 \\
\hline
\end{tabular}

Table 3. Characteristics of Respondents By Age

\begin{tabular}{ccc}
\hline Age & Frequency & $\%$ \\
\hline $25-27$ & 6 & 50 \\
Years old & & \\
$28-30$ & 5 & 41,6 \\
Years old & & \\
$\quad 31-33$ & 1 & 8,3 \\
Years old & & \\
Total & 12 & 100 \\
\hline
\end{tabular}

Table 4. Characteristics of Respondents Based on Length Of Work

\begin{tabular}{ccc}
\hline $\begin{array}{c}\text { Length of } \\
\text { work }\end{array}$ & Frequency & $\%$ \\
\hline $\begin{array}{c}1-5 \text { Years } \\
\text { old }\end{array}$ & 0 & 0 \\
$\begin{array}{c}5-10 \text { Years } \\
\text { old }\end{array}$ & 12 & 100 \\
$>10$ Years \\
old & 0 & 0 \\
Total & 12 & 100 \\
\hline
\end{tabular}

Table 5. The Result of The Worker's Posture Assessment on The Sealing Process

\begin{tabular}{cc}
\hline \multirow{2}{*}{ Assessment } & SealingActivity \\
\hline Upper arm & $45^{\circ}$ \\
Forearm & $50^{\circ}$ \\
Wrist & $0^{\circ}$ \\
Neck & $10^{\circ}$ \\
Body & $10^{\circ}$ \\
Foot & $0^{\circ}$ \\
\hline
\end{tabular}

Table6. Tabulation of Nordic Body Map Questionnaire Based on Types of Pain Complaints on Sealing Process

\begin{tabular}{|c|c|c|c|c|c|c|c|c|c|c|c|c|}
\hline \multirow[b]{2}{*}{ Complaint Type } & \multicolumn{12}{|c|}{ Group code by worker name } \\
\hline & A1 & A2 & A3 & A4 & B1 & B2 & B3 & B4 & $\mathrm{C} 1$ & $\mathrm{C} 2$ & C3 & $\mathrm{C} 4$ \\
\hline $\begin{array}{l}\text { Pain in the upper } \\
\text { neck }\end{array}$ & $\sqrt{ }$ & $\sqrt{ }$ & $\sqrt{ }$ & $\sqrt{ }$ & $\sqrt{ }$ & $\sqrt{ }$ & $\sqrt{ }$ & $\sqrt{ }$ & $\sqrt{ }$ & $\sqrt{ }$ & $\sqrt{ }$ & $\sqrt{ }$ \\
\hline $\begin{array}{l}\text { Pain in the lower } \\
\text { part of the neck }\end{array}$ & $\sqrt{ }$ & $\sqrt{ }$ & $\sqrt{ }$ & $\sqrt{ }$ & $\sqrt{ }$ & $\sqrt{ }$ & $\sqrt{ }$ & $\sqrt{ }$ & $\sqrt{ }$ & $\sqrt{ }$ & $\sqrt{ }$ & $\sqrt{ }$ \\
\hline $\begin{array}{l}\text { Pain in the left } \\
\text { shoulder }\end{array}$ & $\sqrt{ }$ & $\sqrt{ }$ & $\sqrt{ }$ & $\sqrt{ }$ & $\sqrt{ }$ & $\sqrt{ }$ & $\sqrt{ }$ & $\sqrt{ }$ & $\sqrt{ }$ & $\sqrt{ }$ & $\sqrt{ }$ & $\sqrt{ }$ \\
\hline $\begin{array}{c}\text { Pain in the right } \\
\text { shoulder }\end{array}$ & $\sqrt{ }$ & $\sqrt{ }$ & $\sqrt{ }$ & $\sqrt{ }$ & $\sqrt{ }$ & $\sqrt{ }$ & $\sqrt{ }$ & $\sqrt{ }$ & $\sqrt{ }$ & $\sqrt{ }$ & $\sqrt{ }$ & $\sqrt{ }$ \\
\hline $\begin{array}{c}\text { Pain in upper arm } \\
\text { left }\end{array}$ & $\sqrt{ }$ & $\sqrt{ }$ & $\sqrt{ }$ & $\sqrt{ }$ & $\sqrt{ }$ & $\sqrt{ }$ & $\sqrt{ }$ & $\sqrt{ }$ & $\sqrt{ }$ & $\sqrt{ }$ & $\sqrt{ }$ & $\sqrt{ }$ \\
\hline Pain in the back & $\sqrt{ }$ & $\sqrt{ }$ & $\sqrt{ }$ & $\sqrt{ }$ & $\sqrt{ }$ & $\sqrt{ }$ & $\sqrt{ }$ & $\sqrt{ }$ & $\sqrt{ }$ & $\sqrt{ }$ & $\sqrt{ }$ & $\sqrt{ }$ \\
\hline
\end{tabular}




\begin{tabular}{|c|c|c|c|c|c|c|c|c|c|c|c|c|}
\hline $\begin{array}{c}\text { Pain in right upper } \\
\text { arm }\end{array}$ & $\sqrt{ }$ & $\sqrt{ }$ & $\sqrt{ }$ & $\sqrt{ }$ & $\sqrt{ }$ & $\sqrt{ }$ & $\sqrt{ }$ & $\sqrt{ }$ & $\sqrt{ }$ & $\sqrt{ }$ & $\sqrt{ }$ & $\sqrt{ }$ \\
\hline Pain in the waist & $\sqrt{ }$ & $\sqrt{ }$ & $\sqrt{ }$ & $\sqrt{ }$ & $\sqrt{ }$ & $\sqrt{ }$ & $\sqrt{ }$ & $\sqrt{ }$ & $\sqrt{ }$ & $\sqrt{ }$ & $\sqrt{ }$ & $\sqrt{ }$ \\
\hline $\begin{array}{l}\text { Pain in the buttocks } \\
\text { Pain in the butt } \\
\text { Pain in the left } \\
\text { elbow }\end{array}$ & $\sqrt{ }$ & $\sqrt{ }$ & $\sqrt{ }$ & $\sqrt{ }$ & $\sqrt{ }$ & $\sqrt{ }$ & $\sqrt{ }$ & $\sqrt{ }$ & $\sqrt{ }$ & $\sqrt{ }$ & $\sqrt{ }$ & $\sqrt{ }$ \\
\hline $\begin{array}{c}\text { Pain in the right } \\
\text { elbow }\end{array}$ & $\sqrt{ }$ & $\sqrt{ }$ & $\sqrt{ }$ & $\sqrt{ }$ & $\sqrt{ }$ & $\sqrt{ }$ & $\sqrt{ }$ & $\sqrt{ }$ & $\sqrt{ }$ & $\sqrt{ }$ & $\sqrt{ }$ & $\sqrt{ }$ \\
\hline $\begin{array}{l}\text { Pain in the left } \\
\text { forearm }\end{array}$ & $\sqrt{ }$ & $\sqrt{ }$ & $\sqrt{ }$ & $\sqrt{ }$ & $\sqrt{ }$ & $\sqrt{ }$ & $\sqrt{ }$ & $\sqrt{ }$ & $\sqrt{ }$ & $\sqrt{ }$ & $\sqrt{ }$ & $\sqrt{ }$ \\
\hline $\begin{array}{l}\text { Pain in the right } \\
\text { forearm }\end{array}$ & $\sqrt{ }$ & $\sqrt{ }$ & $\sqrt{ }$ & $\sqrt{ }$ & $\sqrt{ }$ & $\sqrt{ }$ & $\sqrt{ }$ & $\sqrt{ }$ & $\sqrt{ }$ & $\sqrt{ }$ & $\sqrt{ }$ & \\
\hline Pain in the left wrist & $\sqrt{ }$ & $\sqrt{ }$ & $\sqrt{ }$ & $\sqrt{ }$ & $\sqrt{ }$ & $\sqrt{ }$ & $\sqrt{ }$ & $\sqrt{ }$ & $\sqrt{ }$ & $\sqrt{ }$ & $\sqrt{ }$ & $\sqrt{ }$ \\
\hline Pain in right wrist & $\sqrt{ }$ & $\sqrt{ }$ & $\sqrt{ }$ & $\sqrt{ }$ & $\sqrt{ }$ & $\sqrt{ }$ & $\sqrt{ }$ & $\sqrt{ }$ & $\sqrt{ }$ & $\sqrt{ }$ & $\sqrt{ }$ & $\sqrt{ }$ \\
\hline Pain in the left hand & $\sqrt{ }$ & $\sqrt{ }$ & $\sqrt{ }$ & $\sqrt{ }$ & $\sqrt{ }$ & $\sqrt{ }$ & $\sqrt{ }$ & $\sqrt{ }$ & $\sqrt{ }$ & $\sqrt{ }$ & $\sqrt{ }$ & $\sqrt{ }$ \\
\hline $\begin{array}{c}\text { Pain in the right } \\
\text { hand }\end{array}$ & $\sqrt{ }$ & $\sqrt{ }$ & $\sqrt{ }$ & $\sqrt{ }$ & $\sqrt{ }$ & $\sqrt{ }$ & $\sqrt{ }$ & $\sqrt{ }$ & $\sqrt{ }$ & $\sqrt{ }$ & $\sqrt{ }$ & $\sqrt{ }$ \\
\hline $\begin{array}{c}\text { Pain in the left thigh } \\
\text { Pain in the right } \\
\text { thigh }\end{array}$ & & & & & & & & & & & & \\
\hline Pain in the left knee & $\sqrt{ }$ & $\sqrt{ }$ & $\sqrt{ }$ & $\sqrt{ }$ & $\sqrt{ }$ & $\sqrt{ }$ & $\sqrt{ }$ & $\sqrt{ }$ & $\sqrt{ }$ & $\sqrt{ }$ & $\sqrt{ }$ & $\sqrt{ }$ \\
\hline $\begin{array}{c}\text { Pain in the right } \\
\text { knee }\end{array}$ & $\sqrt{ }$ & $\sqrt{ }$ & $\sqrt{ }$ & $\sqrt{ }$ & $\sqrt{ }$ & $\sqrt{ }$ & $\sqrt{ }$ & $\sqrt{ }$ & $\sqrt{ }$ & $\sqrt{ }$ & $\sqrt{ }$ & $\sqrt{ }$ \\
\hline Pain in the left calf & $\sqrt{ }$ & $\sqrt{ }$ & $\sqrt{ }$ & $\sqrt{ }$ & $\sqrt{ }$ & $\sqrt{ }$ & $\sqrt{ }$ & $\sqrt{ }$ & $\sqrt{ }$ & $\sqrt{ }$ & $\sqrt{ }$ & $\sqrt{ }$ \\
\hline Pain in the right calf & $\sqrt{ }$ & $\sqrt{ }$ & $\sqrt{ }$ & $\sqrt{ }$ & $\sqrt{ }$ & $\sqrt{ }$ & $\sqrt{ }$ & $\sqrt{ }$ & $\sqrt{ }$ & $\sqrt{ }$ & $\sqrt{ }$ & $\sqrt{ }$ \\
\hline $\begin{array}{c}\text { Pain in the left } \\
\text { ankle }\end{array}$ & $\sqrt{ }$ & $\sqrt{ }$ & $\sqrt{ }$ & $\sqrt{ }$ & $\sqrt{ }$ & $\sqrt{ }$ & $\sqrt{ }$ & $\sqrt{ }$ & $\sqrt{ }$ & $\sqrt{ }$ & $\sqrt{ }$ & $\sqrt{ }$ \\
\hline $\begin{array}{c}\text { Pain in the right } \\
\text { ankle }\end{array}$ & $\sqrt{ }$ & $\sqrt{ }$ & $\sqrt{ }$ & $\sqrt{ }$ & $\sqrt{ }$ & $\sqrt{ }$ & $\sqrt{ }$ & $\sqrt{ }$ & $\sqrt{ }$ & $\sqrt{ }$ & $\sqrt{ }$ & $\sqrt{ }$ \\
\hline Pain in the left leg & $\sqrt{ }$ & $\sqrt{ }$ & $\sqrt{ }$ & $\sqrt{ }$ & $\sqrt{ }$ & $\sqrt{ }$ & $\sqrt{ }$ & $\sqrt{ }$ & $\sqrt{ }$ & $\sqrt{ }$ & $\sqrt{ }$ & $\sqrt{ }$ \\
\hline Pain in the right & $\sqrt{ }$ & $\sqrt{ }$ & $\sqrt{ }$ & $\sqrt{ }$ & $\sqrt{ }$ & $\sqrt{ }$ & $\sqrt{ }$ & $\sqrt{ }$ & $\sqrt{ }$ & $\sqrt{ }$ & $\sqrt{ }$ & $\sqrt{ }$ \\
\hline
\end{tabular}

\section{RESULT and DISCUSSION}

\subsection{Research Description}

\section{- Job Description}

This work posture research is done to employees of departmental packaging company on sealing job. In the packaging department is the work done is packing a good finish in the form of creamer into 25 $\mathrm{kg}$ paper bag packaging which then through several processes to be forwarded to the warehouse. In the sealing process itself is a continuation of the filling process is the initial process of packing the product into $25 \mathrm{~kg}$ packaging. Workers on this sealing process are in charge of fireplaces packing paper bags by folding the ends of open packaging. On sealing work is done by one person according to work instructions. The employee achievement targets at the packaging department are 2000 bags per shift. The activity is performed with a standing position within 12 hours of work with rest time every 1 hour for 10 minutes. Heavy paper bags that have not filled the product $0.326 \mathrm{~kg}$ and heavy paper bag that has been filled $25 \mathrm{~kg}$ product. The results of this observation were measured using RULA method with documentation of worker's posture while doing sealing job. The documentation of the image is then assessed using a score score and a grand score. Then determined the level of action or action level. So it can be known steps to be taken related to the acquisition of grand scores on sealing jobs.

\subsection{Data Analysis}

- The initial position of the strapping body, the wrist of standby face down, and the position of the body approaching with the packaging to facilitate the reach of the hand to fold. 


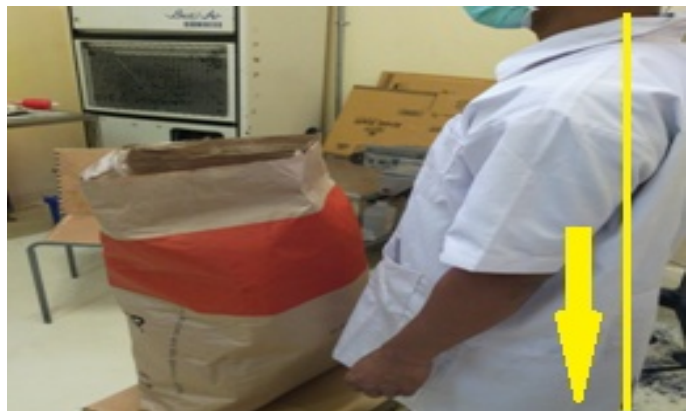

Figure 2 Sealing Body Posture

- Once ready, both wrists hold the packaging and the head is bowed slightly looking into the packaging.

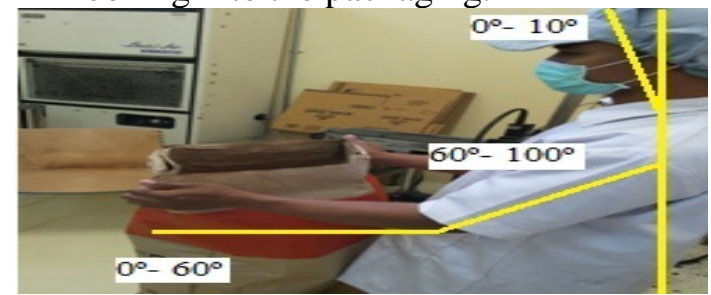

Figure 3 Sealing Body Posture

- $\quad$ The folding process is done by holding the top end of the open package, then pulling right to the right and left wrists for the left wrist.

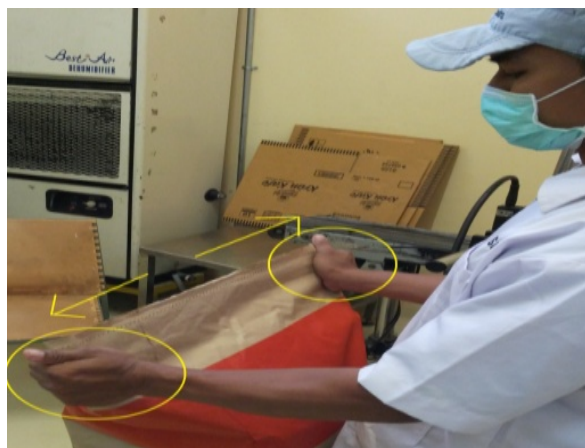

Figure 4 Sealing Body Posture

- After being pulled to the right and to the left, then pushed or bent forward with the second position of the wrist still clutching the end of the pack

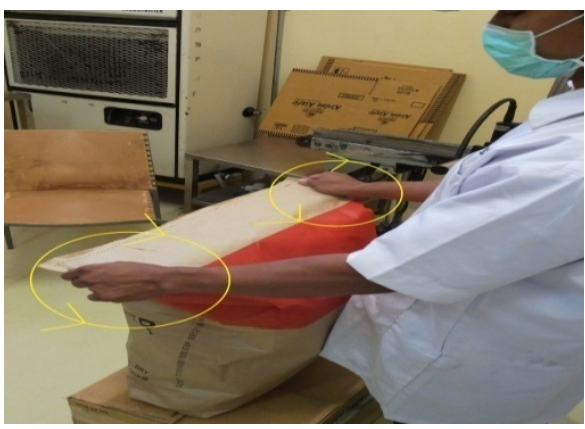

Figure 5 Sealing Body Posture
- After forming the folds on, the packaging tip is pulled back facing upwards

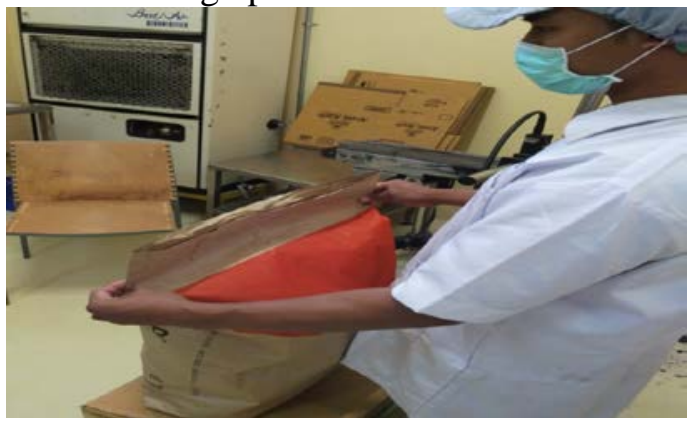

Figure 6 Sealing Body Posture

- After finished the position of the body and wrist again as before

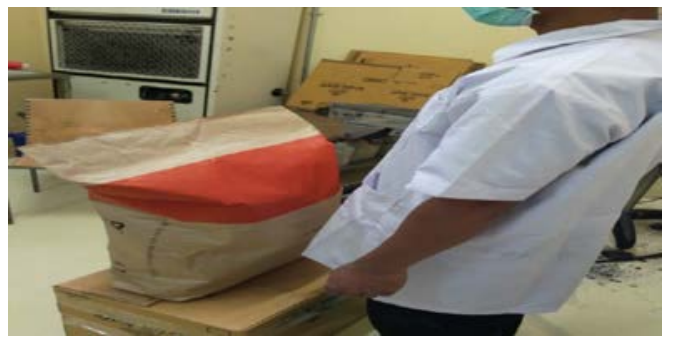

Figure 7 Sealing Body Posture

a. Assessment of group posture score $A$

- Upper arm : Ekstension $>20^{\circ}$ atau flexion $20^{\circ}-45^{\circ}$, score 3

- Forearm : Flexioni $<60^{\circ}$ atau $>100^{\circ}$, score 2

- Forearmwork on the outside of the body (+1), final score 3

- Wrist : in a neutral position score 1

The wrist at work has deviation either ulnar or radial $(+1)$, final score 2

b. Assessment of group posture score $B$

- Neck : Flexion $0^{\circ}-10^{\circ}$, score 1

- Body : Flexion $0^{\circ}-20^{\circ}$, score 2

- Foot : Standing weight weightedly distributed by both feet, there is enough room to change position, score

c. Assessment RULA grand score Assessment of the grand score RULA is based on group posture A scores table is getting a score of 4 and table group $B$ score score obtained score 2 . Then for the loading and deployment of power given 4 $(3+1)$ due to repetitive loading or deployment or static $\geq 10 \mathrm{~kg}$ repeated more than 4 times in 1 minute.

Table 7.Grand score

\section{Score D}

\begin{tabular}{cccccccc} 
Score C & 1 & 2 & 3 & 4 & 5 & 6 & $7+$ \\
\hline 1 & 1 & 2 & 3 & 3 & 4 & 5 & 5
\end{tabular}


$\begin{array}{llllllll}2 & 2 & 2 & 3 & 4 & 4 & 5 & 5\end{array}$

$\begin{array}{llllllll}3 & 3 & 3 & 3 & 4 & 4 & 5 & 6\end{array}$

$\begin{array}{llllllll}4 & 3 & 3 & 3 & 4 & 5 & 6 & 6\end{array}$

$\begin{array}{llllllll}5 & 4 & 4 & 4 & 5 & 6 & 7 & 7\end{array}$

$\begin{array}{llllllll}6 & 4 & 4 & 5 & 6 & 6 & 7 & 7\end{array}$

$\begin{array}{llllllll}7 & 5 & 5 & 6 & 6 & 7 & 7 & 7\end{array}$

$\begin{array}{llllllll}8 & 5 & 5 & 6 & 7 & 7 & 7 & 7\end{array}$

Based on the results of the grand score analysis above, the final score obtained is 7 . Where in the action level of the job is 4 which means that investigation and improvement is needed as soon as possible.

\section{Conclusion}

Based on the description of data processing from the report of posture analysis of workers on the sealing process made by 12 employees in the packaging department can be summed up as follows:

a. The final score is based on the RULA method

The sealing process causes pain complaints with a score of 4 on group A's posture score. In addition, experiencing pain complaints with score 2 on group B post score, score 8 on score $\mathrm{C}$ and score 6 on score $\mathrm{D}$ for grand scoring RULA score got score 7 meaning necessary investigation and repair as soon as possible.

b. Results from Nordic Body Map

- Prior to work, 12 workers did not engage in work activities which meant that they did not have a working risk level.

- After work 12 workers received a grand score score of RULA with a score of 7 which means that investigations and repairs are needed as soon as possible.
- The most common complaints on the upper part of the neck, lower neck, left shoulder, right shoulder, upper left lengabn, right upper lengabn, back, waist, left elbow, right elbow, left wrist, right wrist, hand left, right hand, left knee, right knee, left calf, right calf, left ankle, right ankle, left foot, right foot.

c. To improve the working method causing some pain complaints it is necessary to change the working method.

\section{References}

1. Nurmianto, E. (1998), Ergonomi-Konsep Dasar dan Aplikasinya. Edisi 1, GunaWidya, Surabaya.

2. Sugiyono. (2012), Memahami Penelitian Kualitatif. Bandung: ALFABETA.

3. Suma'mur P.K., Dr, Msc. (1981), Keselamatan Kerja dan Pencegahan Kecelakaan, PT. TokoGunungAgung: Jakarta.

4. Suma'mur P.K., Dr, Msc. (1988), Hygiene Perusahaan dan Kesehatan. CV. Haji Mas Agung, Cetakan ke6. Jakarta.

5. Tarwaka, Solichul, Lilis Sudiajeng. Ergonomi Untuk Keselamatan, KesehatanKerja, danProduktivitas. Surakarta: Universitas Brawijaya Press. 2004.

6. Tarwaka. Dasar-Dasar Pengetahuan Ergonomi dan Aplikasi di Tempat Kerja. (Solo: Harapan Press Solo, 2010).

7. Tarwaka. (2011), Ergonomi Industri, Harapan Press, Solo.

8. Thackray, Richard. (1981), The Stress of Boredom and Monotony: A Consideration of The Evidence. Phychosomatic Medicine, Vol. 43, No. 2. 